\title{
Exploration of Information Mode of College Teaching Management in the Internet Plus Context
}

\author{
Yanxia $\mathrm{Hu}$ \\ School of Foreign Language \\ Jilin Business and Technology College \\ Changchun, China 130062
}

\begin{abstract}
With the extensive application of Internet technology in higher education, the college teaching management should keep pace with the times and make use of modern information technology to reinforce the management. Based on the explanation and elaboration of the internet plus and teaching management informatization, this thesis analyzes the existing problems of the informatization construction of college teaching management, then puts forward the corresponding countermeasures, discusses the informatization mode of college teaching management so as to promote teaching management and improve teaching quality.
\end{abstract}

Keywords-internet plus; informatization mode; teaching management; exploration

\section{INTRODUCTION}

With the development of internet technology, college education has already been in the stage of information. It also makes teaching management informatization to be an inevitable tendency. Today, some colleges have already begun to use informatization mode of teaching management, while there are still some problems. In order to get an effective teaching management, this article analyzes the existing problems and puts forward some countermeasures and discusses the informatization mode of college teaching management.

\section{INTERNET PluS AND COLLEGE TEACHING MANAGEMENT INFORMATIZATION}

\section{A. Content of Internet Plus}

The concept of internet plus was first proposed by the president $\mathrm{Yu}$ Yang of Yi Guan company. Then had been widely spread and applied. Internet plus is not just adding the internet industry and traditional industries together, but also promoting both of them deeper combination and innovating the industry development mode with internet thinking, information and communication technology and internet platform, aiming at multiplying the benefits. [1]

\section{B. College Teaching Management Informatization in the Internet Plus Context}

The informatization modes of college teaching management mainly use the internet to combine information technology and college teaching management together. That is to say, on the basis of internet technology, it integrates modern educational theory through combination of all kinds of information management software, such as networks, PC, mobile phone client and so on. Using scientific and efficient means to achieve optimization of the educational resources allocation.[2] The essence is to use all means including internet and information technology to improve work efficiency and satisfy the needs of teachers and students quickly.[3] The development of teaching management information has a far-reaching significance in deepening education reforms, improving teaching quality and benefits and cultivating innovative talents.

\section{CURRENT PROBLEMS IN INFORMATIZATION MODE OF College Teaching Management}

\section{A. Consciousness of Teaching Management with Internet Is Not Strong}

Numerous college teaching managers have not realized the magnitude of using internet, still accustomed to use traditional teaching mode. They are too lazy to exercise their internet operation skills. Some colleges only make use of simple technology, not take continuous technological innovation in their teaching management.

\section{B. College Teaching Mangers Are in Low Professional Quality}

In some local colleges, college teaching managers are in poor ability of computer application, which making it difficult to conduct teaching management in the internet. This leads to the information teaching management cannot go through smoothly.

\section{Network Teaching Management System Is Incomplete}

One is lack of hardware, the other is incomplete hardware. In the multimedia classrooms, something often happens to facilities, such as slow reflex, sticking fast and indistinctness, which lead to difficulty for students at selective course, teacher login grade and teaching management. It brings great trouble to teachers and students and impacts the effectiveness of work. 


\section{Personalized Teaching Management Cannot Be Guaranteed}

Students and teachers cannot inquire their information and curriculum arrangement in the internet. Teachers cannot personalize their management. Selecting course and independent study are also cannot achieve among students.

\section{E. Inadequate of Politics, Institution and Mechanism}

Teaching management is lack of targeted policies, institution mechanism. Teaching management cannot be guaranteed.

\section{COUNTERMEASURES OF TEACHING MANAGEMENT IN THE INTERNET PLUS CONTEXT}

\section{A. Change Concept and Improve Awareness}

The action plan of internet plus was first proposed by Prime $\mathrm{Li}$, as he delivered the government report in 2015. Next year, ministry of education drawed up "educational information 13th five-year plan". The plan puts forward to promote information technology, lift greatly the capacity of teaching and administration. [4]Those all give teaching management a direction, make educational information to be an inevitable tendency.

\section{B. Strengthen Training and Improve Ability of Teaching Managers}

The college should strengthen the training of teaching managers to improve work ability and establish a concept of management in the internet plus context. Managers also should strengthen its efforts to raise the service and awareness, build an excellent quality technology-class workforce.

\section{Increase Investment and Strengthen the Construction of Internet Hardware Facilities}

Computers network equipment resource database, multimedia equipment and so on are the main hardware facilities in internet plus context. The college may need to increase investment on internet facilities, for example: perfect hardware facilities, expand the network coverage, update equipment and development online learning. On the basis of practical teaching conditions, establishing the school-based teaching management system.

\section{Set up Personalized Management Platform for Teachers and Students}

According to job numbers, teachers can see their schedules and students 'information and develop the teaching activities. Students also can achieve the information about their schedules, examinations and grade on the basis of students numbers. Adhering to the developing mode of human-oriented and realizing the personalized teaching management.

\section{E. Develop Corresponding Politics and Strategies to Ensure Teaching Quality}

At first, to actively conduct corresponding politics and strive to establish a long-term teaching management mechanism. Then, use rewards incentive mechanism to stimulate teachers' initiative, and improve teaching effective and quality.

\section{COllege Information Mode of TEACHING MANAGEMENT IN THE INTERNET PLUS CONTEXT}

\section{A. Set up Course Management Information Platform and Its Enforcement Mode}

1) Set up course management information platform: For application-oriented colleges, we should set up a teaching management platform shared among teachers, students, colleges and companies and build a shared space. The teachers and the companies in different areas together finish curriculum standards, teaching syllabus, unit designs and so on at the same time. The teaching resources of the course can also be uploaded. Teachers can use the platform to achieve online or offline interactive teaching. Students can learn, discuss in pairs and evaluate each other. To ensure that teaching management goes smoothly, teacher-student interaction has to be monitored and measured by university administrative staff. Companies utilize data from the platform as a reference for recruitment.

2) Enforcement mode: Set up a new way to obtain information for preparation, classroom interaction and review after class. Students can also download curriculum resources from the platform. The platform is compatible with a variety of teaching applications App. Through the platform, teachers can use stimulating thinking method to interact with students. Mutual evaluation can be done among students. Expressing opinions and discussion with each other are also available by it. Students may vote on expression of others. Teachers can conduct tests of the students' learning progress.

The curriculum management platform is open to the mobile devices such as: Smart-phone, tablet PC and so on. Students can utilize small moments of time to study, without being restricted by time and place. This platform has broken the restriction of traditional pattern, having realized functions such as resource reading, online Micro-lesson learning, realtime interaction between team members and teachers.

Constructing a multidimensional evaluation system for students. The platform provides data as evaluation criteria such as the time for access to information on the Internet and interaction with teachers. Students upload their assignments to the platform, after teachers correct the homework, students can refer the record through it. Under the arrangement, students would anonymously review their classmates' performances.

At the same time, we certainly set up an effective feedback system, so that students can anonymously review their teacher's teaching method, attitude and materials. 
College may propose correction opinions from students and communicate with teachers after discovering problems. Aiming at existing problems, teachers can communicate with their students through the platform.

Setting up an incentive mechanism for the teaching resources of curriculum. The quantity and quality of teaching materials uploaded by teachers should be considered as an important part for evaluation index of teaching and even as a part of amount of work. To encourage teachers to enrich course resources, perfect course system.

Strengthen the construction of teachers information, through the training of young teachers to drive faculty to participate in the information technology project.

\section{B. Set up Teacher Information Platform and Its Enforcement Mode}

1) Set up teacher information platform: Except for hardware, teachers' quality is greater for the teaching management information. Some college teachers have too low information literacy to adapt to the need of information teaching. So it is necessary for the college to build a platform to manage teachers and provide the skill training for teachers information.

2) Enforcement mode: The college should establish a training program that can manage teachers and docking remote teaching platform. The platform is one of the most important approaches for teachers' further education, which will absolutely promote teachers' professional development. The hours of training are recognized directly on the platform. Based on individual demands such as curriculum resources, learning strategy and so on, we should establish an information management system for teacher learning. Via website, Internet course and cloud education to enhance the professionalism and cultural and scientific quality of teachers, making it possible for everyone to have their own platform for learning and practice.

College builds personal information file system and management systems for teachers, mainly including: curriculum resource, teaching mode and teaching effect.

\section{Set up Student Information Platform and Its Enforcement Mode}

1) Set up student information platform: Students can selectively learn online course and collect learning information through the network platform. The college should establish the platform in order to satisfy their needs to enrich their learning content and improve their learning ability.

2) Enforcement mode: The platform should design systematically according to the following aspects such as learning requirement, learning content and learning effect, which includes course resources, learning strategy, direction of learning activities and evaluation of learning effect. This platform should be convenient for student learning. We also should set up a learning detection system to monitor the learning situation in time, is intended to ensure the quality of learning. After the big data technology is applied in the system, the platform is able to record the learning process of students. It is convincing for teachers to analyze individual learning styles and design more scientific and reasonable teaching strategies for students. The management system mainly includes student information, attendance, course arrangement, learning record, evaluation, credit hour management ,class management ,payment method and so on.

\section{Set up Management Information Platform of Teaching Administrative Department and Its Enforcement Mode}

1) Set up management information platform of teaching administrative department: In order to improve teaching management. the college should establish management information platform of teaching administrative department .

2) Enforcement mode:Firstly, college may establish an internet teaching management department, which designed to provide speedy service and save hours of researching computer technology. Secondly, establish educational administration system to supervise information platforms ,such as courses, teachers, students . Thirdly, establish an internet teaching assessment system, which includes learning motivation, learning process and learning effect. The system pays close attention to the students' ability of search information and absorbing knowledge. To make the transition of the evaluation from traditional way to emphasizing assessing learning process and the interaction between teachers and students in the Internet plus context.

\section{CONCLUSION}

All in all, the college teaching management in the internet plus context should keep pace with the times, based on the requirement of school management, making the development of teachers and students as the starting point and objectiveness. Working to combine network technology and traditional working mode so as to enhance college education and teaching level.

\section{REFERENCES}

[1] Wang Zhouhong. Innovation and Enlightenment of Universities Education Management Mode in the Internet Plus Chinese Adult Education 2017.08 (in Chinese)

[2] Tan Lin. Research on Higher Vocational Teaching Management in the Internet Plus. Education Modernization. 2016.07.16

[3] Li Jiancheng Idea of Building College Administration Education in Jiangsu: Education Management 2016.10

[4] The Ministry of Education of the People's Republic of China on Issuing the Notice o f the 13th Five-Year Plan of Education Informatization [EB/OL].[2017-01-06]. http:// www.more.gov.cn/srcsite/A16/s3342/261606/t20160622269367.html. 